with the normal range. In any case the increases are insufficient to explain the hypertension, since infusions of angiotensin which raise the diastolic pressure of normal subjects by $30 \mathrm{~mm}$. $\mathrm{Hg}$ produce a concentration in the blood that is four or five times larger than that found in patients with renal or essential hypertension. ${ }^{9}$ The levels of renin in the plasma of patients with stenosis of the renal artery may even lie within the normal range, though when these patients also have a low concentration of potassium in the serum the plasma-renin concentration is raised more frequently.; There is strong evidence that angiotensin may have an important role in the regulation of the output of aldosterone, and infusion of angiotensin is one potent stimulus to its secretion. ${ }^{10-12}$ Plasma-renin concentrations are high in patients on a diet restricted in sodium and in patients with adrenal insufficiency. ${ }^{;}$Angiotensin, when infused, accumulates in high concentration in both the kidney and the adrenal glands, ${ }^{13}$ and this provides further evidence that its prime action may be on the adrenal. The release of renin, with the formation of angiotensin and hypersecretion of aldosterone, probably explains the secondary hyperaldosteronism that has been observed in some patients with malignant hypertension or stenosis of the renal artery.

It is doubtful if the pressor action of angiotensin released by renin plays an important part in renal hypertension. (It may have an indirect role by stimulating retention of sodium through secretion of excess aldosterone, but this also appears unlikely.) Most patients with benign hypertension probably do not secrete excessive quantities of aldosterone, ${ }^{10}$ though some have suggested that persistent hypersecretion of small amounts may stimulate retention of sodium and thereby have a cumulative effect on the blood-pressure which is much greater than would be expected. ${ }^{14}$ Long-continued infusions of angiotensin in animals sometimes cause a greater increase in blood-pressure than the same infusions continued for shorter times. However, the dose range for this effect is narrow and the blood-pressure always falls to normal or below normal soon after the infusion is stopped. There seems to be no evidence for a self-sustaining mechanism in these experiments. $^{15}$

If angiotensin is demoted from the role of prime mover in renal hypertension to an important function in the control of sodium metabolism the question still remains, What is the humoral mechanism which brings about renal hypertension? There is a formidable body of evidence that abnormalities of sodium metabolism and of the regulation of fluid volume occur in both experimental and human hypertension, and that

${ }^{1}$ Elliott, D. F., and Peart, W. S., Biochem. F., 1957, 65, 246.

Skeggs, L. T., K 2 h.n, J. R., and Shumway, N. P., Ұ. exp. Med., 1956 103, 301 .

3 Schwyzer, R., and Sieber, P., Chimia, 1956, 10, 265

+ Edelman, R., and Hartroft, P. M., Circ. Res., 1961, 9, 1069.

5 Gross, F., Schaechtelin, G., Brunner, H., and Peters, G., Canad. med Ass. .7., 1964, 90, 258.

${ }^{B}$ de Bono, E., Lee, G. de J., Mottram, F. R., Pickering, G. W., Brown, J. J., Keen, H., Peart, W. S., and Sanderson, P. H., Clin. Sci., 1963 25, 123.

' Brown, J. J., Davies, D. L., Lever, A. F., and Robertson, J. I. S., Canad. med. Ass. F., 1964, 90, 201

Helmer, O. M., and Judson, W. E., Circulation, 1963, 27, 1050

Helmer, O. M., and Judson, W. E., Circulation, 1963, 27, 1050. Biron, P., Tremblay, G., Roy, P., and Cartier, P., Canad. med. Ass. $\mathcal{F}$., 1961, 90, 263.

" Laragh, J. H., Angers, M., Kelly, W. G., and Lieberman, S., f. Amer. med. Ass., 1960, 174, 234.

11 Biron, P., Koiw, E., Nowaczynski, W., Brouillet, J., and Genest, J., F. clin. Invest., 1961, 40, 338 .

1: J. Chretien, M., Koiw, E., and Genest, J., Brit. med. F., 1962, 1, 1569

${ }_{13}$ Bumpus, F. M., Smeby, R. R., Page, I. H., and Khairallah, P. A., Canad.

med. Ass. F., 1964, 90, 190.
it Gross, F., in Essential Hypertension, ed. K. D. Bock and P. T. Cottier, 1960. Berlin, Springer.

1s Dickinson, C. J., and Lawrence, J. R., Lancet, 1963, 1, 1354.
16 Ledingham, J. M., and Cohen, R. D., Canad. med. Ass. F., 1964, 90, 292. the balance between peripheral resistance and cardiac output may be altered during the development of experimental renal hypertension. ${ }^{16}$ This now seems the most promising lead for investigators into the cause of human renal hypertension.

\section{Sequelae of Tuberculous Meningitis}

Seventeen years ago streptomycin was introduced into clinical medicine and was used for the treatment of tuberculous meningitis. This transformed the previously hopeless prognosis, though the mortality still remained high, the treatment was arduous, and many of the survivors were left with physical, intellectual, or psychological sequelae, some of which were due to drug toxicity. Experience in the use of streptomycin, and especially the introduction of P.A.S. and isoniazid, led to greatly improved results with a higher survival rate and fewer sequelae, and even better results were obtained by using corticosteroids in selected, difficult cases. ${ }^{1}$ Deafness, which was largely due to long courses of intrathecal streptomycin and to the short vogue of using dihydrostreptomycin, is now uncommon. Several studies $^{2-5}$ have appeared in the last few years dealing with the long-term follow-up of children who have recovered from tuberculous meningitis.

A general picture has emerged with many interesting features, not least of which is the remarkable ability of young children to recover completely from such grave lesions as unconsciousness lasting for months, hemiplegia, total blindness, deafness, and convulsions. Many factors influence the ultimate outcome. The condition and the age of the patient on admission are the most important, and the efficiency and the urgency of treatment also play a vital part. Much further improvement, both physical and intellectual, may take place even after the completion of treatment. Some sequelaesuch as diabetes insipidus, sexual precocity, or sexual infantilism-may not appear for some years. Late relapses may also occur. Thus the final results of treatment can be evaluated after prolonged observation. G. Nickerson and P. N. MacDermot ${ }^{2}$ performed detailed psychometric tests on 50 children treated in Montreal up to about 1956 and found that the group as a whole was below average in intelligence (with a mean I.Q. of 73), and that 16 children were mentally deficient. Younger children and those who had convulsions fared worst. ${ }^{1}$ J. Lorber ${ }^{3}$ studied 100 children in detail. These were the survivors $(59 \%)$ out of 170 treated between 1947 and 1955, and the length of follow-up was between 5 and 13 years. On examination 77 children were found to be normal, and 23 had various physical and mental sequelae varying from a trivial facial weakness to profound intellectual and physical disorganization. An I.Q. below 100 was found in 71 of the 100 children, including 6 with amentia, but there were also 7 with an I.Q. of 120 or higher. Most of the patients came from the lower socio-economic groups, which partly accounted for the lower I.Q. levels than in an average population. All but six received education at appropriate schools and two went to university. In this series there

\footnotetext{
'Lorber, J., Brit. med. F., 1960, 1, 1309.

2 Nickerson, G., and MacDermot, P. N., Pediatrics, 1961, 27, 68

${ }^{3}$ Lorber, J., ibid., 1961, 28, 778.

Wasz-Höckert, O., and Donner, M., Acta paediat. (Uppsala), 1963, Supp!. No. 141, p. 7 .

Todd, R. M., and Neville, J. G., Arch. Dis. Childh., 1964, 39, 213.
} 
was very little evidence of emotional disturbance or of character changes. Eighty-four patients had normal hearing and three were totally deaf. Three were blind, including two with amentia, though optic atrophy (as judged by the ophthalmoscope) was present in four others who had normal visual acuity and visual fields. Choroidal tubercles were still present in 31 , but these caused no symptoms. Convulsions persisted in eight children, but abnormal E.E.G. findings were far commoner. Twelve children had paralytic lesions, including seven cases of hemiplegia, and intracranial calcification was present in 45 . In many cases calcification was not associated with any detectable lesions, but among those with the more extensive basal calcifications were the blind or sexually precocious children. The incidence of sequelae was closely connected with the stage of the disease and the adequacy of treatment, and all the six children with gross brain damage were under 3 years of age on admission. Very similar results were recorded later by $\mathrm{O}$. Wasz-Höckert and M. Donner ${ }^{4}$ in Finland.

Recently R. M. Todd and J. G. Neville ${ }^{5}$ have studied 65 out of 73 known survivors from a series of 194 children (37\% surviving) treated between 1947 and 1957 . Of the living children $48 \%$ were in the early stage of the disease on admission. All were followed up for 3-14 years after admission. Their intellectual picture conformed to the previous pattern, with six mentally defective subjects and six borderline defectives. All these 12 had had very severe meningitis during their illness, though not necessarily on admission. In this series severe retardation was found to occur even in children who were over 6 years of age at the onset. Two subjects were of superior intelligence and 38 were average or bright normal. More detailed psychiatric assessment showed a rather higher incidence of emotional disturbance than other workers have reported, $20(30 \%)$ of the subjects being mildly maladjusted and $9(13 \%)$ severely maladjusted. Physical sequelae were present in one-third of Todd and Neville's patients-a similar finding to those in the other series. Delayed onset of puberty was noted in two cases.

The steadily improving results of treatment of tuberculous meningitis in recent years which are reported in these and other papers are impressive. Given reasonably early diagnosis and efficient treatment in an experienced centre, the overwhelming majority of children with tuberculous meningitis should now make an uneventful recovery without sequelae.

\section{Exchange Transfusion for Hyperbilirubinaemia}

Bilirubin is constantly being produced from the breakdown of haemoglobin, but its level in the plasma seldom exceeds $1 \mathrm{mg}$. per $100 \mathrm{ml}$. because excretion is so rapid. It is not soluble in water, but when conjugated within the liver cell forms bilirubin glucuronide, which being water-soluble is excreted in the bile. The conjugating mechanism is so efficient that even a greatly increased breakdown of red cells rarely results in a level of bilirubin in the plasma that is greater than $6 \mathrm{mg}$. per $100 \mathrm{ml}$.

Once conjugation has occurred the accumulation of bilirubin glucuronide is not dangerous, even when biliary obstruction is present, partly because it is excreted in the urine (and therefore does not reach very high levels in the blood) but also because it is not toxic to nerve cells. Liver disease may lead to the retention of both bilirubin and conjugated bilirubin, but dangerous concentrations are not reached. Unconjugated bilirubin (hyperbilirubinaemia) reaches high levels only when the conjugating mechanism is defective, as in rare congenital disorders of bilirubin metabolism and in newborn, especially premature, infantsfor the enzyme systems in the liver are not fully developed at birth. Hyperbilirubinaemia may occur in a newborn infant even when red-cell destruction is normal, but if haemolytic anaemia is present the risk is greatly increased. Since bilirubin is soluble in lipids there is a danger that it will enter intact cells and if nerve cells are involved produce kernicterus and frequently death of the infant. However, maturation of the conjugating mechanism within 7 to 10 days of birth can be confidently expected, and if bilirubin can be maintained at a "safe" level brain damage can be averted. Most workers regard a level of $20-25 \mathrm{mg}$. per $100 \mathrm{ml}$. as indication for treatment, but some would also take into account the concentration of proteins ${ }^{1}$ and the bilirubin-binding capacity ${ }^{2}$ of the plasma, though many other factors influence the development of kernicterus. ${ }^{3}$ Only in haemolytic disease of the newborn can hyperbilirubinaemia be anticipated and prevented, for early exchange transfusion will minimize haemolysis by replacing damaged erythrocytes with normal cells. $^{4}$ Should hyperbilirubinaemia develop despite this, or from any other cause, treatment is urgently required.

Though many problems still remain in haemolytic disease of the newborn, that of preventing stillbirth is paramount. The management of a patient with a poor obstetric history has to steer a difficult course between the Scylla of possible hydrops foetalis if the pregnancy is allowed to proceed after the 34 th week and the Charybdis of prematurity if delivery is induced well before term. The condition of the foetus in utero can now be assessed by estimating the bilirubin content of a sample of liquor obtained by amniocentesis. ${ }^{6}$ At p. 594 of this week's B.M.7. Dr. C. A. Holman and Mrs. Jadwiga Karnicki report five cases in which this technique was used followed by intrauterine transfusion of the foetus. One baby with hydrops foetalis was born prematurely and could not be saved. The remaining four were all born alive and three survived, the fourth developing cardiac arrest at the time of exchange transfusion. Holman and Karnicki have little doubt about the value of intrauterine transfusion, though they consider that some need will always remain for premature induction of labour.

In the plasma bilirubin is carried as a complex with albumin and therefore cannot be removed by dialysis. It is removed by exchange transfusion, but is quickly replaced by

\footnotetext{
${ }^{1}$ Ostrow, J. D., Schmid, R., and Samuelson, D., F. clin. Invest., 1963,

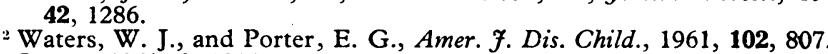

${ }^{2}$ Waters, W. J., and Porte

' Lancet, 1962, 1, 1291.
Walker, W., and Murray, S., Brit. med. F., 1954, 2, 126.

5 and Neligan, G. A., ibid., 1955, 1, 681.

i ibid., 1964, 2, 136.

: Lathe, G. H., ibid., 1955, 1, 192.

${ }^{8}$ Valaes, T., Acta Paediat., 1963, 52, 149, Suppl.

${ }^{9}$ Odell, G. B., F. clin. Invest., 1959, 38, 823.

10 Kitchen, W. H., Krieger, V. I., and Smith, M. A., Med. F. Aust., 1960, 2, 781 .

1.2 Reports of F. Pediat., 1960, 57, 876

12 Reports of Ross Conferences on Pediatric Research, Suppl. No. 1

${ }^{1} 3$ Ruys, J. H., and van Gelderen, H. H., F. Pediat., 1962, 61, 413.

14 David, G., Proc. 7th Cong. Europ. Soc. Haemat., Part 11, 1960. London.

is Bowen, W. R., Porter, E., and Waters, W. J., A.M.A. F. Dis. Child., 1959, 98, 568 .

16 Bentley, H. P., Ziegler, N. R., and Krivit, W., Amer. F. Dis. Child., $1960,99,8$.

1: Novak, M., Polacek, K., and Melichar, V., Biol. Neonat., 1962, 4, 310.

18 Walford, R. L., Anderson, R. E., and Doyle, P., Vox Sang., 1961, 6, 80.
} 